\title{
Association Between Vitamin D Dosing Regimen and Fall Prevention in Long-term Care Seniors
}

\author{
Gilbert T. Chua ${ }^{1}$ and Roger Y. Wong, BMSC, MD, FRCPC, FACP ${ }^{2}$ \\ ${ }^{1}$ LKS Faculty of Medicine, University of Hong Kong, Hong Kong, China; \\ ${ }^{2}$ Division of Geriatric Medicine, University of British Columbia, Vancouver, Canada
}

DOI: $10.5770 /$ cgj.v14i4.23

\begin{abstract}
\section{Introduction}

The effectiveness of vitamin $\mathrm{D}$ in reducing falls among longterm care (LTC) seniors remains nonconclusive. We reviewed how vitamin D dosing regimen could affect rate of fall and number of fallers among LTC seniors.
\end{abstract}

\section{Methods}

We conducted a systematic literature review. Studies were selected by two independent reviewers based on study characteristics (age 75 or older), quality assessment (primary analysis randomized controlled trials), and outcome (rate of fall and number of fallers). Analyses of all trials following trials using daily standard dosage (800-1000 IU) only were performed to compare daily standard dosage with intermittent supratherapeutic dosage in fall prevention.

\section{Results}

Seventy-nine studies were identified, with 28 selected by reviewers (kappa 0.98), and four RCT were conducted in LTC. Daily standard dosage provides greater reduction in rate of fall by $16 \%$, which was statistically significant. However, reduction in number of fallers remained statistically insignificant even taking dosing regimen into account.

\section{Conclusions}

Daily standard dosage of vitamin D has greater benefits in reducing fall rate than that of intermittent supratherapeutic doses, but not in number of fallers. This could imply that vitamin $\mathrm{D}$ is useful in preventing fall recurrence rather than first fall. Prospective studies randomizing LTC seniors to different dosing regimens are warranted.

Keywords: long-term care, elderly, vitamin D, falls

\section{INTRODUCTION}

Falls are common among older people. Seniors living in long-term care (LTC) facilities have higher average rate of falls of 1.5-1.7 per person annually, comparing with community-dwelling seniors who had an average rate of 0.65 per person annually. ${ }^{(1,2)}$ LTC seniors are also prone to suffer from more serious consequences, with $10 \%-25 \%$ having a fracture or laceration. ${ }^{(3)}$ These injuries further expose the patients to surgically related risks and complications of immobilization, including pulmonary embolism, infection, and physical deconditioning. ${ }^{(4)}$ In addition, falls in LTC seniors are very costly. They result in more injuries, longer hospital stays, more medico-legal issues and over USD 4000 in excess charges per hospitalization, ${ }^{(5)}$ which ranges from USD 319 in minor, noninjurious falls to USD 22,368 in multi-injury falls. ${ }^{(6)}$

Risk factors of falls can be divided into intrinsic and extrinsic factors. Intrinsic factors include cognitive, visual, neurologic, and gait impairment, as well as cardiovascular diseases, muscle weakness, and medication influences such as antihypertensives; while extrinsic factors are those related to the environment such as wet floors and poor lighting. ${ }^{(7)}$ Among all these factors, cognitive impairment is one of the main contributing factors. ${ }^{(8)}$ Nevertheless, multiple interventions have been identified as being beneficial in preventing falls in seniors. They include minimization of medications, initiation of exercise program, treating vision impairment, managing postural hypotension and cardiac abnormalities, improving footwear and home environment, and prescription of vitamin $\mathrm{D}^{(9)}$

In particular, vitamin $\mathrm{D}$ use is an interesting intervention. Vitamin D is a group of fat-soluble steroids that can be naturally obtained through two sources. Ultraviolet B irradiation from the sun is the primary source, which converts 7-dehydrocholesterol in the skin to cholecalciferol (vitamin $\mathrm{D}_{3}$ ). Vitamin $\mathrm{D}$ can also be obtained through diet, which consists of cholecalciferol and ergocalciferol (vitamin $\mathrm{D}_{2}$ ). A hydroxyl group is then added to vitamin $\mathrm{D}_{2}$ and $\mathrm{D}_{3}$ in the liver, forming $25(\mathrm{OH}) \mathrm{D}_{2}$ and $25(\mathrm{OH}) \mathrm{D}_{3}$. Finally, 
another hydroxyl group is added in the kidney, forming the active form of vitamin $\mathrm{D}$ (calcitriol, or $1,25(\mathrm{OH}) \mathrm{D}_{2}$ or $\left.1,25(\mathrm{OH}) \mathrm{D}_{3}\right)^{(10)}$

A recent review has suggested histological and interventional evidence between vitamin $\mathrm{D}$ deficiency and muscle weaknesses. ${ }^{(11)}$ Severe vitamin D deficiency to the extent of osteomalacia causes proximal and lower limb muscle weaknesses, with histological evidence of predominant type II muscle atrophy, widening of interfibrillary spaces, fatty infiltration, fibrosis, and the presence of glycogen granules without signs of inflammatory reaction. In less extreme cases, $30 \%$ of muscle biopsies revealed features of vitamin $\mathrm{D}$ insufficiency-related myopathies. ${ }^{(12,13)}$ Vitamin D insufficiency leads to poor absorption of dietary calcium and phosphate, thus leading to reduced muscle strength. Interaction between vitamin $\mathrm{D}$ and vitamin $\mathrm{D}$ receptors promotes protein synthesis and positively influences muscle mass and strength. Vitamin D receptors on muscle cell membrane are essential for intracellular calcium distribution and regulation. Also vitamin D stimulates uptake of inorganic phosphate, which is essential for the production of energy-rich compounds such as ATP and creatine phosphate for muscle contraction. ${ }^{(14)}$ Supplementation of vitamin D has been shown to improve relative muscle fiber composition and fibers area of type IIa muscle fibers, and has also been reported to have an effect on antigravity muscles, supported by the improvement in postural equilibrium tests. ${ }^{(11)}$

Although there is no consensus of which vitamin D level is defined as deficient, ${ }^{(15)}$ it has been suggested that serum vitamin D level should be at least $75 \mathrm{nmol} / \mathrm{L}$, which implies numerous elderly in the community and LTC facilities would be deficient in Vitamin D, thus supplementation would be warranted. ${ }^{(16)}$ It is a safe supplement to prescribe without significant adverse effects prescribed at standard doses or supratherapeutic doses. In a randomized controlled trial using weekly doses of $8400 \mathrm{IU}$ of vitamin $\mathrm{D}_{3}$, incidences of hypercalcemia and hypercalciuria were reported to be insignificant comparing with placebo group, with no kidney stone formation. ${ }^{(17)}$ Clinical trials in LTC settings adopting standard 800-1000 IU of vitamin $\mathrm{D}_{2}$ reported to have no adverse outcomes. ${ }^{(18)}$ In a recent publication summarizing clinical practice guidelines updated by American Geriatrics Society and British Geriatrics Society on fall prevention, it was strongly recommended that daily vitamin D supplementation of $800 \mathrm{IU}$ shall be considered in LTC residents who are known to be vitamin D deficient, having gait or balance problems, and who are at risk for falls. ${ }^{(9)}$ Also, a recent guideline published by the Society of Obstetricians and Gynecologists of Canada (SOGC) also recommended that postmenopausal women should acquire 800 IU of vitamin D and $1200 \mathrm{mg}$ of calcium per day in conjunction with other interventions to improve bone health. ${ }^{(19)}$

In spite of all these benefits, results of fall prevention by vitamin D in LTC have been nonconclusive. In a recent
Cochrane review, vitamin D supplementation results in a significant reduction in rate falls among LTC seniors by $28 \%$, but insignificant in number of falls. ${ }^{(20)}$ However, various randomized controlled trials have adopted different dosing regimen. Most adopted a daily high-dosing regimen which has been shown to be effective in fall prevention, while some adopted quarterly or yearly higher dosing regimen which generated insignificant results. Therefore, in this systematic review, we would like to take a closer look on how dosing regimen of vitamin $\mathrm{D}$ influences rate of falling and number of fallers among LTC seniors.

\section{METHODS}

\section{Search Strategy and Data Extraction}

We conducted an extensive systematic literature review using standard databases including PubMed, Medline and Evidence Based Medicine Reviews, with the support of a professional health science librarian, searching for studies in English on fall prevention among seniors by vitamin D and its analogues over a ten-year period since 2000 .

Search terms include those related to vitamin D ("1,25-dihydroxycholecalciferol", "25-hydroxycholecalciferol", "1,25-dihydroxyvitamin D", "25-hydroxyvitamin D", "vitamin D", "ergocalciferol", "cholecalciferol”, "calcitriol", "hydroxycholecalciferol", "dihydroxycholecalciferol", "calcifediol", "vitamin D2", "vitamin D3", "paricalcitol", "vitamin D analogs and derivatives"), fall ("fall", "fall prevention", "primary fall prevention", "secondary fall prevention", "tertiary fall prevention"), and elderly ("elders", "aged", "older adults", "seniors").

\section{Inclusion Criteria}

Inclusion criteria were mean or median age of 75 years old or older, primary analysis randomized controlled trials, studies targeting at long-term care seniors only, and primary outcome being rate of fall. Our review focused on very old seniors (i.e., mean or median age of 75 years old or older), because older seniors are more likely to fall than younger seniors. ${ }^{(8)}$ We believe that such stratification will lead to a more specific result that guides future clinical practice.

\section{Exclusion Criteria}

Exclusion criteria were articles studying on subjects of mean or median age younger than 75 years old; communitydwelling seniors or unspecified populations; primary outcome other than fall, such as cancer prevention or osteoporosis; article types including observational, cohort, case-control studies, systematic review and meta-analysis, letter-to-theeditor, and clinical guidelines; and articles where full texts are not available or have been withdrawn. 


\section{Outcome Measures}

Our primary outcome is rate of fall, and the secondary outcome is number of fallers. We analyzed the studies by performing systematic review of all the trials included, followed by using only standard dosage of 800-1000 IU of vitamin $\mathrm{D}$, in order to compare the outcome between standard high dose with intermittent supratherapeutic dose.

\section{Studies Identification}

Seventy-nine studies were initially identified and reviewed by two independent reviewers. Forty-three articles were excluded because mean or median age was younger than 75 years old. Full texts were unavailable in six articles. One article was being withdrawn from the literature and was not available. There was disagreement in one article between the reviewers, as one reviewer did not agree the article fits into the inclusion criteria. The article was reviewed in detail and discussed between the reviewers. Consensus was reached based on the fact that the article was not related to vitamin $\mathrm{D}$ and fall prevention and the article was excluded. Twentyeight articles were retrieved with an inter-rater reliability of 0.98 . They were reviewed in details. Twenty-two studies were excluded because study populations were community-dwelling seniors but not LTC seniors. Two studies were further excluded for being not a primary analysis RCT. Finally, four studies were included for systematic review. These studied LTC seniors of mean or median age of 75 or older, and are of primary analysis randomized controlled trials. (Figure 1)

\section{RESULTS}

Four studies were identified, ${ }^{(21-24)}$ involving 3,717 LTC seniors (Table 1). Among the four studies, three of them adopted standard daily high oral doses of vitamin D ranging from 800-1000 IU, while one study (Law et al. ${ }^{(24)}$ ) prescribed 100,000 IU oral doses every 3 months. Two studies used vitamin $\mathrm{D}_{2}$, while the other two used vitamin $\mathrm{D}_{3}$. Two studies provided calcium supplements to both study arms. Baseline mean serum 25-hydroxyvitamin D levels between treatment and control group were significantly different in one study. Compliance rate ranged from $68 \%$ to $100 \%$.

Regarding the number of falls, there was a significant $28 \%$ reduction (OR $0.72,95 \%$ CI $0.55-0.95$ ) with the magnitude of reduction further increased to $44 \%$ after taking dosing regimen into account, and remained statistically significant (OR $0.56,95 \%$ CI $0.33-0.93$ ). This indicated that daily high dose of vitamin $\mathrm{D}$ is more effective than quarterly supratherapeutic doses in reducing fall rate. (Table 2, Figures 2(A) and 2(B))

Regarding the number of fallers, a $2 \%$ reduction was noted, yet statistically insignificant (OR $0.98,95 \%$ CI 0.89 1.09). After taking dosing regimen into account by removing the study conducted by Law et al., there is a further faller

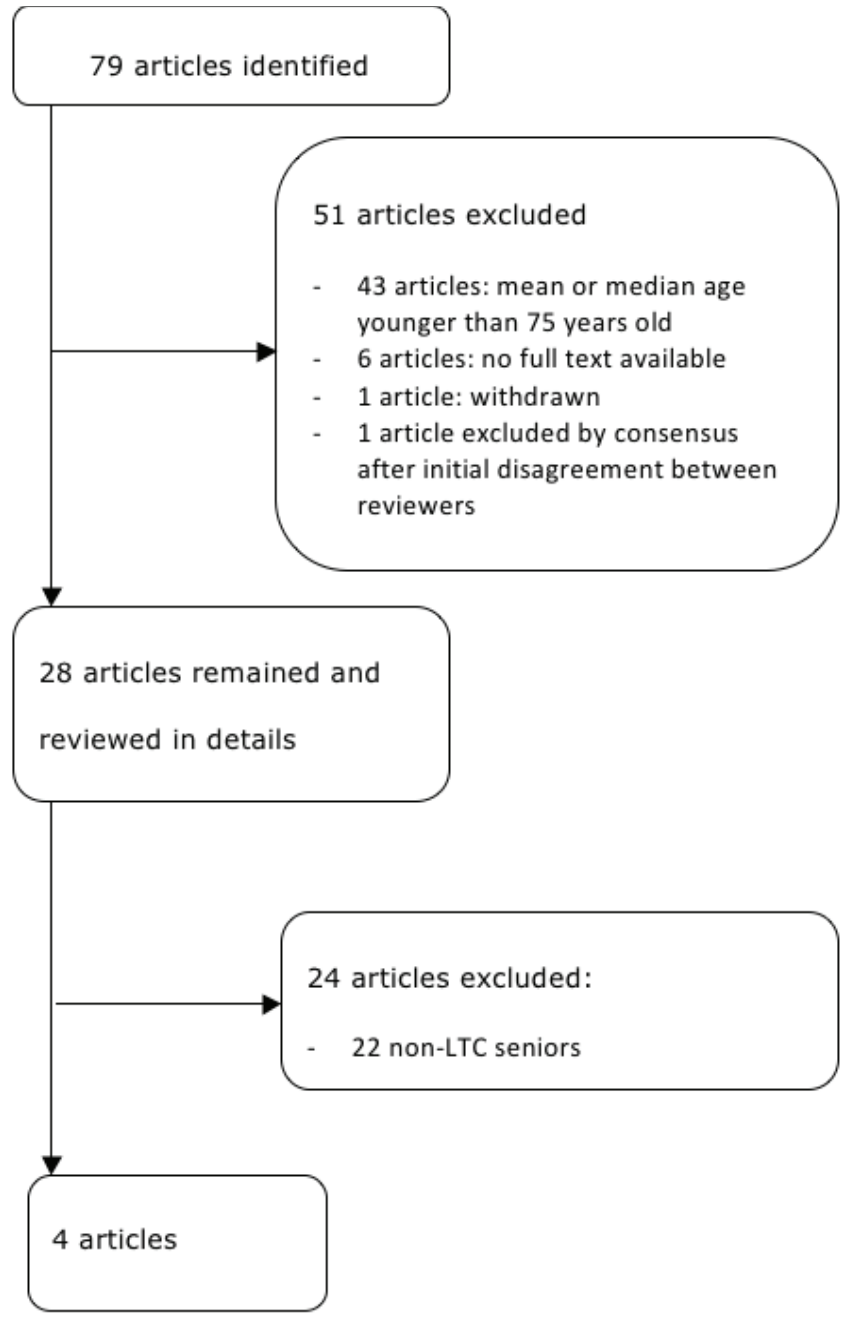

FIGURE 1. Flow diagram of article inclusion for review

reduction to $12 \%$ (OR 0.88, 95\% CI 0.72-1.09); however, such a reduction remained insignificant. This indicated that vita$\min \mathrm{D}$, both daily high doses and quarterly supratherapeutic doses, are not effective in reducing number of fallers. (Table 3, Figures 3(A) and 3(B))

\section{DISCUSSION}

As far as we know, this is the first systematic review that takes dosing regimen of vitamin $\mathrm{D}$ into account in fall prevention among LTC seniors. We found that intermittent supratherapeutic doses could possibly undermine the effectiveness of vitamin $\mathrm{D}$ in fall prevention. In this systematic review of four double-blinded, randomized, controlled trials, vitamin $\mathrm{D}$ at all doses was found to be effective in reducing rate of falls, with statistical significance, by $28 \%$. Exclusion of the study using 100,000 IU quarterly was found to have a further increase of effectiveness by $16 \%$. However, there was no effect on reducing number of fallers, even after taking dosing regimen into account. Therefore, in attempt to reduce fall 
TABLE 1.

Randomized controlled trials included for review

\begin{tabular}{|c|c|c|c|c|c|c|c|}
\hline Study & Country & Intervention & $\begin{array}{l}\text { Length of } \\
\text { follow-up } \\
\text { (months) }\end{array}$ & $\begin{array}{c}\text { Study } \\
\text { population size }\end{array}$ & Mean age & $\begin{array}{c}\text { Mean baseline } \\
\text { 25-hydroxyvitamin } \\
D(\mathrm{nmol} / \mathrm{L})\end{array}$ & $\begin{array}{c}\text { Compliance } \\
(\%)\end{array}$ \\
\hline
\end{tabular}

\begin{tabular}{|c|c|c|c|c|c|c|c|c|c|c|c|}
\hline & & Treatment & Control & & Treatment & Control & Treatment & Control & Treatment & Control & \\
\hline $\begin{array}{l}\text { Broe } \\
2007^{17}\end{array}$ & USA & $\begin{array}{l}\text { Vitamin } \mathrm{D}_{2} \\
800 \mathrm{IU} \text { daily }\end{array}$ & Placebo & 5 & 23 & 25 & 89 & 86 & $53.5^{\mathrm{a}}$ & $53^{\mathrm{a}}$ & 97.6 \\
\hline $\begin{array}{l}\text { Flicker } \\
2005^{18}\end{array}$ & Australia & $\begin{array}{l}\text { Vitamin } \mathrm{D}_{2} \\
1000 \mathrm{IU} \text { daily } \\
+600 \mathrm{mg} \\
\text { calcium daily }\end{array}$ & $\begin{array}{c}\text { Placebo } \\
+600 \mathrm{mg} \\
\text { calcium } \\
\text { daily }\end{array}$ & 24 & 313 & 312 & 83.6 & 83.3 & \multicolumn{2}{|c|}{$59^{\mathrm{b}}$} & 68 \\
\hline $\begin{array}{l}\text { Bischoff } \\
2003^{19}\end{array}$ & Switzerland & $\begin{array}{l}\text { Vitamin } \mathrm{D}_{3} \\
800 \mathrm{IU} \text { daily } \\
+1200 \mathrm{mg} \\
\text { calcium daily }\end{array}$ & $\begin{array}{l}1200 \mathrm{mg} \\
\text { calcium } \\
\text { daily }\end{array}$ & 4 & 62 & 60 & 84.9 & 85.4 & $72.5^{\mathrm{a}, \mathrm{c}}$ & $27.8^{\mathrm{a}, \mathrm{c}}$ & 100 \\
\hline $\begin{array}{l}\text { Law } \\
2006^{20}\end{array}$ & UK & $\begin{array}{c}\text { Vitamin } \mathrm{D}_{2} \\
100,000 \text { every } \\
3 \text { months }\end{array}$ & $\begin{array}{l}\text { No vitamin } \\
\text { D }\end{array}$ & 10 & 1762 & 1955 & 85 & 85 & \multicolumn{2}{|c|}{ Not provided $^{d}$} & 98 \\
\hline
\end{tabular}

${ }^{a}$ figures were converted from $\mathrm{ng} / \mathrm{ml}$ to $\mathrm{nmol} / \mathrm{L}(1 \mathrm{ng} / \mathrm{ml}=2.5 \mathrm{nmol} / \mathrm{L})$

$\mathrm{b}$ a sample of 18 subjects was taken, no comparison between treatment and control group was provided

${ }^{\mathrm{c}} \mathrm{p}<0.0001$

${ }^{d}$ only proportions of subjects in different vitamin D levels are provided

TABLE 2.

Vitamin D dosing regimen and number of falls

\begin{tabular}{|c|c|c|c|c|c|}
\hline \multirow[t]{2}{*}{ Studies } & \multirow[t]{2}{*}{$\begin{array}{l}\text { Regimen } \\
\text { (oral dosing) }\end{array}$} & \multicolumn{2}{|c|}{$\begin{array}{c}\text { Rate of Fall (falls/ } \\
\text { person/year) }\end{array}$} & \multirow[t]{2}{*}{$\begin{array}{l}\text { Odds } \\
\text { Ratio }\end{array}$} & \multirow[t]{2}{*}{$95 \% \mathrm{Cl}$} \\
\hline & & Treatment & Control & & \\
\hline $\begin{array}{l}\text { Broe } \\
2007^{(21)}\end{array}$ & 800 IU daily & 0.94 & 2.97 & 0.28 & $\begin{array}{c}0.10- \\
0.76\end{array}$ \\
\hline $\begin{array}{l}\text { Flicker } \\
2005^{(22)}\end{array}$ & 1000 IU daily & 1.06 & 1.43 & 0.73 & $\begin{array}{l}0.57- \\
0.95\end{array}$ \\
\hline $\begin{array}{l}\text { Bischoff } \\
2003^{(23)}\end{array}$ & 800 IU daily & 1.21 & 2.75 & 0.51 & $\begin{array}{c}0.23- \\
1.14\end{array}$ \\
\hline $\begin{array}{l}\text { Composite } \\
\text { of first } 3 \\
\text { studies }\end{array}$ & & & & 0.56 & $\begin{array}{l}0.33- \\
0.93\end{array}$ \\
\hline $\begin{array}{l}\text { Law } \\
2006^{(24)}\end{array}$ & $\begin{array}{c}100,000 \text { every } 3 \\
\text { months }\end{array}$ & 1.99 & 2.29 & 0.87 & $\begin{array}{c}0.80- \\
0.94\end{array}$ \\
\hline $\begin{array}{l}\text { Composite } \\
\text { of all } 4 \\
\text { studies }\end{array}$ & & & & 0.72 & $\begin{array}{l}0.55- \\
0.95\end{array}$ \\
\hline
\end{tabular}

rate among LTC seniors, daily high oral doses ranging from 800-1000 IU is preferred to intermittent supratherapeutic doses according to current evidence. This observation could possibly suggest vitamin D has an effect in reducing fall recurrence instead of preventing LTC seniors from sustaining first fall. Future prospective trials with head-to-head comparison of various vitamin D doses are needed to confirm this observation.

Our findings, in terms of vitamin D dosing regimen, were parallel with other randomized controlled trials studying community-dwelling seniors recently published. This could possibly suggest that intermittent supratherapeutic doses were not beneficial in all seniors. Sanders et al. ${ }^{(25)}$ studied 2256 community-dwelling senior women with mean age of 76 , prescribing annual supratherapeutic doses of 500,000 IU of cholecalciferol or placebo. It was found to have an increased in risk of falling by $15 \%$ (95\% CI 1.02-1.30) and fractures by $26 \%$ (95\% CI 1.00-1.59). Smith et al. ${ }^{(26)}$ studied 9,440 seniors aged 75 years old or older, and found that annual intramuscular injection of 300,000 IU of vitamin $D_{2}$ was not effective in reducing fall risks (hazard ratio 0.98 , 95\% CI 0.93-1.04), or nonvertebral fractures (hazard ratio 1.09, 95\% CI 0.93-1.28). Although another trail conducted by Trivedi et al. ${ }^{(27)}$ prescribing 100,000 IU oral vitamin $\mathrm{D}_{3}$ to community-dwelling seniors was shown to be beneficial in 
(A)

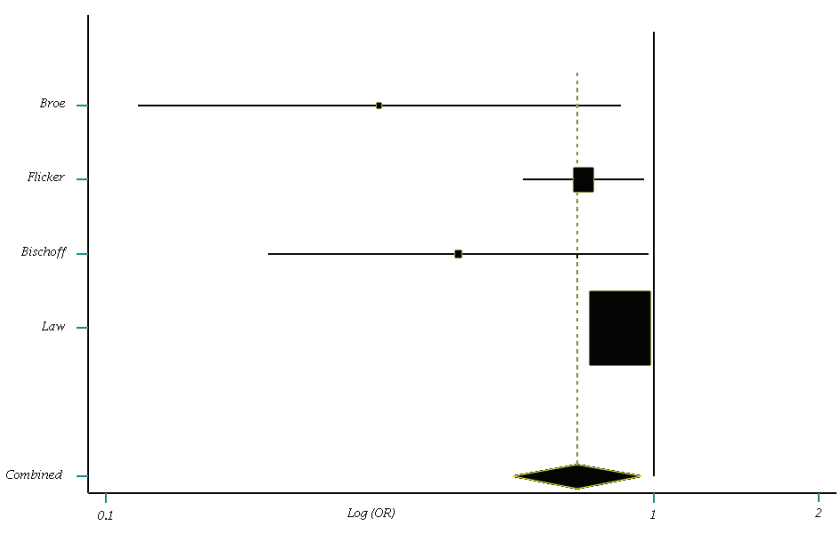

$\mathrm{OR}=0.72 ; 95 \% \mathrm{CI}=0.55-0.95 ; p=0.019$;

Test for heterogeneity: $\mathrm{Q}=7.549$ on 3 degrees of freedom $(p=0.056)$

(B)

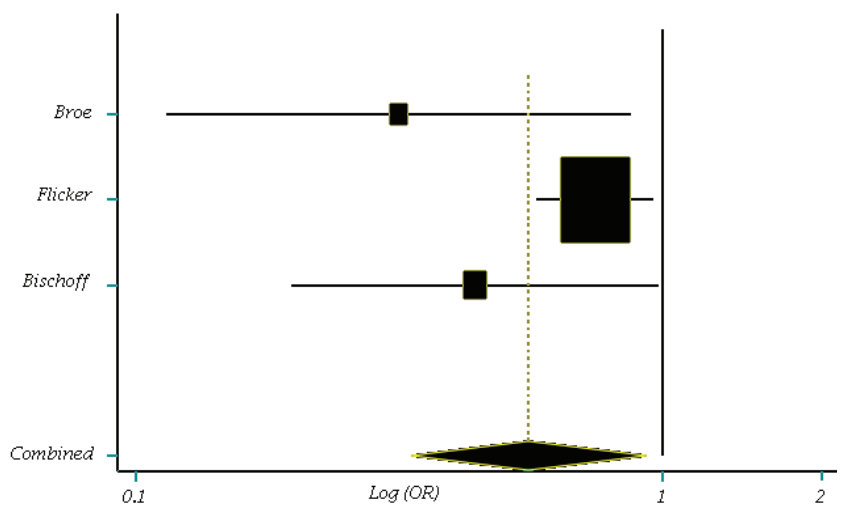

$\mathrm{OR}=0.56 ; 95 \% \mathrm{CI}=0.333-0.930 ; p=0.025$

Test for heterogeneity: $\mathrm{Q}=3.827$ on 2 degrees of freedom $(p=0.148)$

FIGURE 2. Forest plot of vitamin D dosing regimen and number of falls

fracture reduction, the protective effect was only marginal, with $95 \%$ confidence interval being 0.61 to 0.99 .

Nevertheless, daily high oral doses have been proven to be effective in fall prevention. In a metaanalysis conducted by Bischoff-Ferrari et al., ${ }^{(28)}$ it was confirmed that daily vitamin D of $700 \mathrm{IU}$ to $1000 \mathrm{IU}$ is beneficial in fall prevention in both institutionalized and ambulatory seniors, which was not influenced by the supplementation of calcium and types of vitamin D provided. However, there was no information whether higher doses could be more effective.

There are currently no good basic science mechanisms that could fully explain why intermittent supratherapeutic doses failed to prevent falls. From our observation, we hypothesize that there might be a U-shaped curve when the benefit in fall prevention is plotted against dosage of vitamin D supplement. Doses lower than 700 IU are ineffective, while supratherapeutic doses of 100,000 IU or higher
TABLE 3 .

Vitamin D dosing regimen and number of fallers

\begin{tabular}{|c|c|c|c|c|c|}
\hline \multirow[t]{2}{*}{ Studies } & \multirow[t]{2}{*}{$\begin{array}{c}\text { Regimen } \\
\text { (oral dosing) }\end{array}$} & \multicolumn{2}{|c|}{$\begin{array}{c}\text { Proportion of fallers } \\
\text { (\%) [n] }\end{array}$} & \multirow[t]{2}{*}{$\begin{array}{l}\text { Odds } \\
\text { Ratio }\end{array}$} & \multirow[t]{2}{*}{$\begin{array}{r}95 \% \\
C I\end{array}$} \\
\hline & & Treatment & Control & & \\
\hline $\begin{array}{l}\text { Broe } \\
2007^{(21)}\end{array}$ & 800IU daily & $\begin{array}{c}22 \\
{[5 / 23]}\end{array}$ & $\begin{array}{c}44 \\
{[11 / 25]}\end{array}$ & 0.44 & $\begin{array}{r}0.15- \\
1.28\end{array}$ \\
\hline $\begin{array}{l}\text { Flicker } \\
2005^{(22)}\end{array}$ & 1000IU daily & $\begin{array}{c}54 \\
{[170 / 313]}\end{array}$ & $\begin{array}{c}59 \\
{[185 / 312]}\end{array}$ & 0.86 & $\begin{array}{l}0.69 \\
1.07\end{array}$ \\
\hline
\end{tabular}

$\begin{array}{lccccc}\text { Bischoff } & \text { 800IU daily } & 23 & 30 & 0.7 & 0.31- \\ 2003^{(23)} & & {[14 / 62]} & {[18 / 60]} & & 1.56\end{array}$

Composite of
$0.88 \quad 0.72$

1.09

$\begin{array}{cccccc}\text { Law } 2006^{(24)} & 100,000 \text { every } & 44 & 43 & 1.03 & 0.93- \\ & 3 \text { months } & {[770 / 1762]} & {[833 / 1955]} & & 1.14\end{array}$

Composite of

$0.98 \quad 0.89$ all 4 studies seem to be ineffective as well. As a result, vitamin D may have a bimodal distribution of benefit in our body. Studies concerning vitamin D and peripheral artery diseases have shown that higher doses could promote potentially angiotoxic effects in animal models, leading to more vascular calcification, arterial stiffness, and left ventricular hypertrophy. ${ }^{(29)}$ However, whether such property is applicable in fall prevention remains unknown. More studies will be needed.

This review has several limitations. The four randomized controlled trials were studied in different countries: Australia, Switzerland, UK, and USA. Ethnicities and exposure to lengths of daylight are different, which could influence our body synthesis of vitamin D. Also, subjects in these studies have different fall profiles. Some of them have experienced falls or fractures, while some did not. Other factors that contribute to the heterogeneity include differences in baseline vitamin D levels and compliance rate. There is also limited number of primary analysis, randomized, controlled trials that studied LTC seniors of older age available for analysis. Trials included in this review have small population sizes, which could have undermined the power of this analysis. There is a potential for publication bias in this review, but analysis in this aspect was not performed due to limited technical support. 
(A)

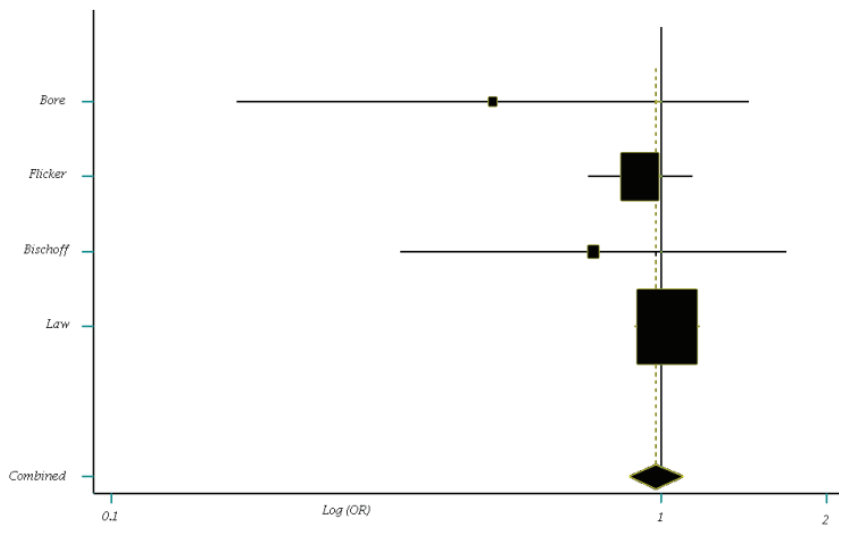

$\mathrm{OR}=0.98 ; 95 \% \mathrm{CI}=0.874-1.099 ; p=0.732$

Test for heterogeneity: $\mathrm{Q}=2.765$ on 3 degrees of freedom $(p=0.429)$

(B)

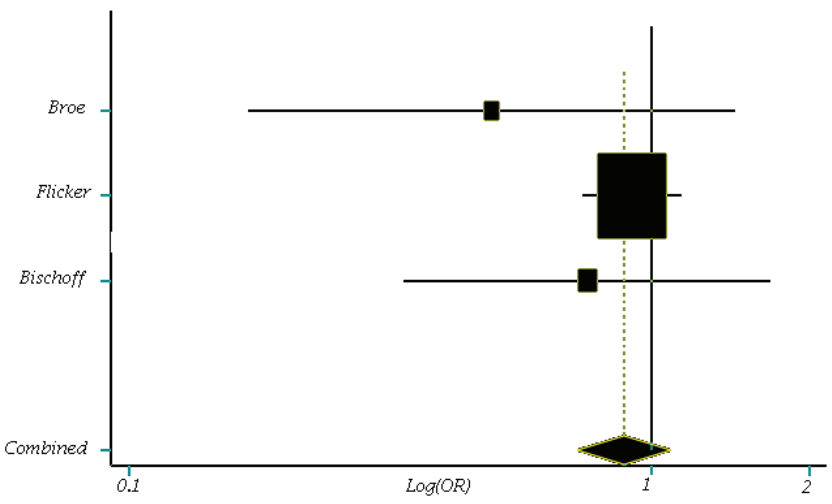

$\mathrm{OR}=0.883 ; 95 \% \mathrm{CI}=0.718-1.087 ; p=0.242$

Test for heterogeneity: $\mathrm{Q}=1.384$ on 2 degrees of freedom $(p=0.500)$

FIGURE 3. Forest Plot of vitamin D dosing regimen and number of fallers

\section{CONCLUSION}

Vitamin D of 800-1000 IU prescribed in a daily basis is more effective in reducing fall rate than quarterly supratherapeutic doses of 100,000 IU by $16 \%$ among LTC seniors of 75 years old or older. However, vitamin D at any doses is not effective in reducing number of fallers. Such a difference could possibly be acknowledged by the fact that vitamin D is useful in preventing fall recurrence rather than first fall. Further studies are warranted to confirm whether intermittent supratherapeutic doses are ineffective in fall prevention among LTC seniors.

\section{ACKNOWLEDGEMENTS}

We would like to thank Ms. Karen MacDonell for her support in performing the literature search, and Dr. Henry Kwok for assisting with data analysis.

\section{CONFLICT OF INTEREST DISCLOSURES}

The authors have no conflicts of interest to declare.

\section{REFERENCES}

1. Rubenstein LZ, Josephson KR, Robbins AS. Falls in the nursing home. Ann Intern Med. 1994;121(6):442-451.

2. Rubenstein LZ. Falls in older people: epidemiology, risk factors and strategies for prevention. Age Ageing. 2006;35(Suppl 2):ii37-ii41.

3. Vu MQ, Weintraub N, Rubenstein LZ. Falls in nursing home: are they preventable? J Am Med Dir Assoc. 2005;6(3 Suppl):S53-S58.

4. Becker C, Rapp K. Fall prevention in nursing homes. Clin Geriatr Med. 2010;26(4):693-704.

5. Inouye SK, Brown CJ, Tinetti ME. Medicare nonpayment, hospital falls, and unintended consequences. $N$ Engl J Med. 2009;360(23):2390-2393.

6. Sorensen SV, de Lissovoy G, Kunaprayoon D, et al. A taxonomy and economic consequences of nursing home falls. Drugs Aging. 2006;23(3):251-262.

7. Fuller GF. Falls in the elderly. Am Fam Physician. 2000;61(7):2159-2168.

8. Krueger PD, Brazil K, Lohfeld LH. Risk factors for falls and injuries in a long-term care facility in Ontario. Can J Public Health. 2001;92(2):117-120.

9. Panel on Prevention of Falls in Older Persons, American Geriatrics Society and British Geriatrics Society. Summary of the updated American Geriatrics Society/British Geriatrics Society clinical practice guideline for prevention of falls in older persons. J Am Geriatr Soc. 2011;59(1):148-157.

10. Fosnight SM, Zafirau WJ, Hazelett SE. Vitamin D supplementation to prevent falls in the elderly: evidence and practical considerations. Pharmacotherapy. 2008;28(2):225-234.

11. Annweiler C, Montero-Odasso M, Schott AM, et al. Fall prevention and vitamin $\mathrm{D}$ in the elderly: an overview of the key role of the non-bone effects. J Neuroeng Rehabil. 2010;7:50-63.

12. Skaria J, Katiyar BC, Srivastava TP, et al. Myopathy and neuropathy associated with osteomalacia. Acta Neurol Scand. 1975;51(1):37-58.

13. Mastaglia FL, Ojeda VJ, Sarnat HB, et al. Myopathies associated with hypothyroidism: a review based upon 13 cases. Aust N Z J Med. 1988;18(6):799-806.

14. Fabbriciani G, Pirro M, Leli C, et al. Diffuse muscoskeletal pain and proximal myopathy: do not forget hypovitaminosis D. J Clin Rheumatol. 2010;16(1):34-37.

15. Bolland MJ, Grey A, Cundy T, et al. Defining vitamin D deficiency. N Z Med J. 2007;120(1263):U2760.

16. Bischoff-Ferrari HA. Vitamin D: what is an adequate vitamin D level and how much supplementation is necessary? Best Pract Res Clin Rheumatol. 2009;23(6):789-795.

17. Lips P, Binkley N, Pfeifer M, et al. Once-weekly dose of 8400 IU vitamin $\mathrm{D}_{3}$ compared with placebo: effects on neuromuscular 


\section{CHUA: VITAMIN D DOSING REGIMEN AND FALL PREVENTION}

function and tolerability in older adults with vitamin D insufficiency. Am J Clin Nutr. 2010;91(4):985-991.

18. Demontiero O, Herrmann M, Duque G. Supplementation with vitamin $\mathrm{D}$ and calcium in long-term care residents. $\mathrm{J} \mathrm{Am} \mathrm{Med}$ Dir Assoc. 2011;12(3):190-194.

19. Reid RL, Blake J, Abramson B, et al. Menopause and osteoporosis update 2009. SOGC clinical practice guideline No. 222, January 2009. J Obstet Gynaecol Can. 2009;31(1):S1-S49.

20. Cameron ID, Murray GR, Gillespie LD, et al. Interventions for preventing falls in older people in nursing care facilities and hospitals. Cochrane Database of Systematic Reviews. 2010; Issue 1.

21. Broe KE, Chen TC, Weinberg J, et al. A higher dose of vitamin D reduces the risk of falls in nursing home residents: a randomized, multiple-dose study. J Am Geriatr Soc. 2007;55(2):234-239.

22. Flicker L, MacInnis RJ, Stein MS, et al. Should older people in residential care receive vitamin D to prevent falls? Results of a randomized trial. J Am Geriatr Soc. 2005;53(11):1881-1888.

23. Bischoff HA, Stahelin HB, Dick W, et al. Effects of vitamin D and calcium supplementation on falls: a randomized controlled trial. J Bone Miner Res. 2003;18(2):343-351.

24. Law M, Withers H, Morris J, et al. Vitamin D supplementation and the prevention of fractures and falls: results of a randomised trial in elderly people in residential accommodation. Age Ageing. 2006;35(5):482-486.
25. Sanders KM, Stuart AL, Williamson EJ, et al. Annual highdose oral vitamin $\mathrm{D}$ and falls and fractures in older women: a randomized controlled trial. JAMA. 2010;303(18):1815-1822.

26. Smith $\mathrm{H}$, Anderson $\mathrm{F}$, Raphael $\mathrm{H}$, et al. Effect of annual intramuscular vitamin $\mathrm{D}$ on fracture risk in elderly men and women - a population-based, randomized, double-blind, placebocontrolled trial. Rheumatology. 2007;46(12):1852-1857.

27. Trivedi DP, Doll R, Khaw KT. Effect of four monthly oral vitamin D3 (cholecalciferol) supplementation on fractures and mortality in men and women living in the community: randomised double blind controlled trial. $B M J$. 2003;326(7387):469.

28. Bischoff-Ferrari HA, Dawson-Hughes B, Staehelin HB, et al. Fall prevention with supplemental and active forms of vitamin D: a meta-analysis of randomised controlled trials. BMJ. 2009;339:b3692.

29. Gaddipati VC, Kuriacose R, Copeland R, et al. Vitamin D deficiency: an increasing concern in peripheral arterial disease. J Am Med Dir Assoc. 2010;11(5):308-311.

Correspondence to: Roger Y. Wong, BMSC, MD, FRCPC, FACP, 7153 - 2775 Laurel Street, Vancouver, British Columbia, V5Z 1M9 Canada

E-mail: roger.wong@ubc.ca 